\title{
Rumen passage kinetics of forage- and concentrate-derived fiber in dairy cows
}

\author{
M. Krämer, ${ }^{1}$ P. Lund, and M. R. Weisbjerg \\ Department of Animal Science, Aarhus University, AU Foulum, Blichers Allé 20, PO Box 50, DK-8830 Tjele, Denmark
}

\begin{abstract}
Rumen passage kinetics of forage and concentrate fiber were analyzed to determine intrinsic feed effects and extrinsic ration effects on the retention time of fiber in the rumen. Sixteen Danish Holstein cows (557 $\pm 37 \mathrm{~kg}$ of body weight, $120 \pm 21 \mathrm{~d}$ in milk, mean \pm SD), 8 fitted with ruminal cannulas, were used in a completely randomized block experiment. Treatments differed in forage type (corn silage vs. grass silage) and forage:concentrate ratio (50:50 vs. $75: 25$ on organic matter basis). Fiber passage kinetics were studied based on rumen evacuations and on marker excretion profiles in feces fitted to 1 and 2 pool models. Each cow received ytterbium $(\mathrm{Yb})$-labeled fiber of the forage fed in the ration, samarium (Sm)-labeled fiber of the forage not fed in the ration, and concentrate fiber labeled with lanthanum (La), all as a single pulse dose. Nineteen fecal grab samples were taken per cow. Rumen liquid passage was studied using chromium-EDTA dosed as a single pulse into the rumen, followed by sampling of rumen liquid from both the ventral and medial rumen. $\mathrm{Ru}-$ men mean retention time did not differ between forages when based on Yb-excretion profiles but was numerically longer for grass silage- than for corn silage-based rations using rumen evacuation data. Liquid rate of passage did not differ when calculated from medial or ventral rumen liquid samples, indicating that estimates for the probability of rumen liquid escape were independent of rumen sampling site. Total mean retention time decreased from forage fiber to concentrate fiber to liquid. The forage type itself (corn silage or grass silage) rather than the ration composition seemed to determine the total-tract retention time of forage fiber. Key words: corn, grass, ytterbium, samarium
\end{abstract}

\section{INTRODUCTION}

Fiber is a major energy source in ruminant feedstuffs. Fiber digestion and passage behavior determine the net

Received September 11, 2012.

Accepted January 24, 2013.

${ }^{1}$ Corresponding author: Monika.Kramer@agrsci.dk energy value of a ration because the cell contents are almost completely digestible. Fiber digestibility in the rumen is the result of the competitive processes digestion and passage and, although increased retention time of feed particles in the rumen increases digestibility, it also decreases feed intake (Huhtanen et al., 2006). Determining the limiting factor for rumen passage of feed particles is therefore of great interest, and data showing the rate-limiting step for particle passage are scarce in the literature.

Fractional rate of passage can be affected by extrinsic or intrinsic factors. Extrinsic factors are related to animal and ration characteristics (Huhtanen et al., 2006), whereas intrinsic factors - particle size, rate of particle size reduction, and functional specific gravity - are determined by feed type (forage vs. concentrate, forage type, and species), stage of maturity, leaf to stem ratio, and growth number (Lund, 2002; Kuoppala et al., 2009, 2010).

Feedstuff type influences the rate of particle breakdown and the distribution between large and small particles in the rumen mat. Bruining et al. (1998) observed a higher proportion of large particles in the rumen particulate DM after feeding grass silage compared with corn or lucerne silage. Lund et al. (2006) found longer rumen retention times (RRT) for grass silage than for corn silage. Tropical C4 grasses such as corn, however, have been shown to break less easily compared with temperate C3 grasses (Wilson and Kennedy, 1996), thus suggesting a longer RRT for corn silage than for grass silage.

Longer retention times of forage compared with concentrate particles have been reported (Colucci et al., 1982, 1990) and are related to larger particle size and lower specific gravity of forage compared with concentrate particles (Huhtanen et al., 2006). Ration composition alters passage kinetics, as a decreasing forage:concentrate $(\mathbf{F}: \mathbf{C})$ ratio increases the RRT of particles (Huhtanen and Jaakkola, 1993), and the effect of decreasing $\mathrm{F}: \mathrm{C}$ ratio on $\mathrm{RRT}$ is more pronounced at low levels of feed intake compared with high levels (Colucci et al., 1990).

Passage studies have been done with the help of particulate-associated markers (Udén et al., 1980), rare- 
earth labeled fiber (Ellis and Huston, 1968), and the rumen evacuation technique (Robinson et al., 1987). Rumen evacuation using indigestible NDF (iNDF) as internal marker yielded higher rumen particulate retention times than Yb-labeled particle excretion profiles fitted to various rumen pool models (Ellis et al., 1994; Huhtanen and Kukkonen, 1995; Lund, 2002).

Pond et al. (1988) showed that the retention of fiber in the rumen is an age-dependent process, and Lund et al. (2007) showed that potentially digestible NDF (pdNDF) has a slower passage rate than iNDF. Models used to describe fiber passage and digestion in the rumen differ in the number of pools and, thereby, in the assumptions about age dependency of the rate parameters (Ellis et al., 1994). These models have the common feature of a sequential particle passage through the different pools and are based on the assumption that the passage of small particles out of the rumen is the rate-limiting step for the disappearance of particles via passage (Huhtanen et al., 2006). Models that estimate NDF digestibility based on kinetic parameters for feed evaluation purposes often consist of 2 pools with age-independent fractional passage rates (Allen and Mertens, 1988). Modern feed evaluation systems take extrinsic characteristics into account when estimating fractional rate of passage, whereas differences between forage types are often not taken into account (NRC, 2001; Fox et al., 2004; Volden, 2011). Krizsan et al. (2010), however, showed in a meta-analysis that inclusion of forage type in estimation of fractional passage rates used for feed evaluation for ruminants increased the precision of rumen digestibility estimates for carbohydrate and protein.

The hypotheses were that extrinsic (ration) characteristics influence passage kinetics relatively more than intrinsic (forage type) characteristics and that corn silage fiber remains in the rumen longer than grass silage fiber. The objectives were to study intrinsic (feed type) and extrinsic (ration) effects on passage kinetics.

\section{MATERIALS AND METHODS}

\section{Animals and Feeding}

The experiment complied with the guidelines of Danish Ministry of Justice law number 382 (June 10, 1987) act number 726 (September 9, 1993) concerning experiments with animals and the care of experimental animals. Sixteen Danish Holstein cows $(557 \pm 37 \mathrm{~kg}$ of BW, $120 \pm 21$ DIM, mean \pm SD; 12 second-parity and 4 third-parity cows) were used in a block experiment. Eight cows (second parity) were fitted with ruminal cannulas (\#1C; Bar Diamond, Parma, ID), and animals were blocked according to cannulation. Ruminally cannulated animals were further blocked according to DMI (mean of the week preceding the experiment) and intact cows according to parity.

Cows within the blocks were randomly allocated to 1 of 4 experimental rations. The experiment lasted 37 $\mathrm{d}$, including an adaptation period of $17 \mathrm{~d}$. Cows were housed in an insulated tie-stall barn and milked twice daily at 0515 and $1530 \mathrm{~h}$. Cows were fed equal amounts of DM at each of the 3 daily feedings at 0500,1300 , and $2100 \mathrm{~h}$. Cows were fed ad libitum with $10 \%$ in excess of their expected DMI during the first $11 \mathrm{~d}$ to determine the individual ad libitum DMI. During the following $6 \mathrm{~d}$, cows were adapted to restricted feeding, which was set to 95\% of each cow's individual DMI. All animals had ad libitum access to water. Feed allocation was adjusted once per week based on the actual DM content of the TMR.

Rations were based on corn silage (variety Adept) harvested October 26, 2010, with a theoretical chopping length of $8.5 \mathrm{~mm}$, and with addition of ensiling additive Lalsil Fresh (Lactobacillus buchneri NCIMB $40788>6.00 \times 10^{6} \mathrm{cfu} / \mathrm{g}$; Lallemand Animal Nutrition, Blagnac, France) or on late-cut, primary growth perennial ryegrass silage ( $<8 \%$ clover) cut on June 15,2010 , with a theoretical chopping length of $19.2 \mathrm{~mm}$.

Corn silage was ensiled in a bunker silo and re-ensiled for experimental purposes in round bales with 11 layers of 25- $\mu \mathrm{m}$ plastic using an Orkel MP 2000 Compactor processor (Orkel A/S, Fannrem, Norway). Grass was prewilted $2 \mathrm{~d}$ before ensiling to a DM content of about $40 \%$. After precision chopping, the material was transported to a clean area, mixed thoroughly, and compressed into round bales as described for corn silage to ensure homogeneous material and constant quality during the experiment. Four concentrate mixtures were formulated to supplement the 2 forages and fulfill lactating dairy cow requirements of NorFor (Volden, 2011). The 4 concentrate mixtures differed in ingredient and mineral composition (Table 1). Urea was included to balance the protein content between corn silage and grass silage (Table 1). Concentrate mixtures had a low concentration of NDF (95 to $104 \mathrm{~g} / \mathrm{kg}$ of DM) with 6 to $11 \mathrm{~g}$ of iNDF $/ \mathrm{kg}$ of DM (Table 2).

Corn silage or grass silage was fed in a TMR with a 75:25 or 50:50 F:C ratio (OM basis), which resulted in 4 rations: corn silage-based ration with 75:25 F:C ratio (C75), corn silage-based ration with 50:50 F:C ratio (C50), grass silage-based ration with 75:25 F:C ratio (G75), and grass silage-based ration with 50:50 F:C ratio (G50; Table 3).

\section{Labeling Technique}

Forage fiber $(5.76 \mathrm{~kg}$ DM of corn silage and $5.35 \mathrm{~kg}$ DM of grass silage) was labeled with either ytterbium 
Table 1. Ingredients of the 4 concentrate mixtures

\begin{tabular}{|c|c|c|c|c|}
\hline \multirow[b]{2}{*}{ Component (\% of DM) } & \multicolumn{4}{|c|}{ Concentrate mixture $^{1}$} \\
\hline & 1 & 2 & 3 & 4 \\
\hline Wheat & 56.1 & 52.1 & 58.8 & 57.6 \\
\hline Soybean meal, decorticated & 28.1 & 26.0 & 29.4 & 28.8 \\
\hline Molasses, sugar beet & 9.4 & 8.7 & 9.8 & 9.6 \\
\hline $\mathrm{TiO}_{2}{ }^{2}$ & 0.3 & 0.5 & 0.3 & 0.6 \\
\hline $\mathrm{NaCl}$ & & & 0.5 & 1.0 \\
\hline Vitamin-mineral premix ${ }^{3}$ & 1.9 & 3.5 & 1.0 & 1.9 \\
\hline Vitamin ADE premix ${ }^{4}$ & 0.3 & 0.5 & 0.3 & 0.6 \\
\hline $\mathrm{CaCO}_{3}$ & 1.3 & 2.3 & & \\
\hline $\mathrm{NaHCO}_{3}$ & 1.6 & 3.0 & & \\
\hline $\mathrm{Na}_{2} \mathrm{SO}_{4}$ & 0.2 & 0.5 & & \\
\hline Urea & 1.0 & 2.9 & & \\
\hline
\end{tabular}

${ }^{1}$ Concentrate mixture 1 in corn silage: 50:50 ration, mixture 2 in corn silage: $75: 25$, mixture 3 in grass silage: 50:50, and mixture 4 in grass silage: $75: 25$.

${ }^{2}$ External marker not used in the present study.

${ }^{3}$ Vitamin-mineral premix (VM 2, Vitfoss, Gråsten, Denmark): Ca, 16 g/100 g of DM; P, 4.5 g/100 g of DM; $\mathrm{Mg}, 6 \mathrm{~g} / 100 \mathrm{~g}$ of DM; Na, $8 \mathrm{~g} / 100 \mathrm{~g}$ of DM; Cl, $8 \mathrm{~g} / 100 \mathrm{~g}$ of DM; S, $0.08 \mathrm{~g} / 100 \mathrm{~g}$ of DM; vitamin A, $546 \mathrm{IU} / \mathrm{g}$; vitamin $\mathrm{D}_{3}, 173 \mathrm{IU} / \mathrm{g}$; vitamin E, 3,640 mg/kg; Mn, 3,640 mg/kg; Cu, $820 \mathrm{mg} / \mathrm{kg} ; \mathrm{Co}, 23 \mathrm{mg} / \mathrm{kg} ; \mathrm{Zn}, 4,090$ $\mathrm{mg} / \mathrm{kg}$; Se, $45 \mathrm{mg} / \mathrm{kg}$.

${ }^{4}$ Vitamin ADE premix: vitamin A, 2,500 IU/g; vitamin $\mathrm{D}_{3}, 200 \mathrm{IU} / \mathrm{g}$; vitamin $\mathrm{E}, 22,000 \mathrm{mg} / \mathrm{kg}$.

$(\mathrm{Yb})$ or samarium $(\mathrm{Sm})$, whereas a mixture of the 4 pelleted concentrates (13.05 kg DM of concentrate mixture $1 ; 13.91 \mathrm{~kg}$ DM of concentrate mixture $2 ; 12.51 \mathrm{~kg}$ DM of concentrate mixture $3 ; 12.74 \mathrm{~kg}$ DM of concentrate mixture 4) was labeled with lanthanum (La). The mixture included $1.27 \mathrm{~kg}$ of fiber from each concentrate. The fiber fraction was extracted by boiling each feedstuff for $1 \mathrm{~h}$ in water with $200 \mathrm{~mL}$ of a commercial detergent without enzymes (Deny, A/S Blumøller, Middelfart, Denmark). Feedstuffs were washed in hot tap water to ensure removal of the detergent. The respective marker was dissolved in $7 \mathrm{~L}$ of demineralized water and mixed with the fiber residue. Sixty-seven grams of $\mathrm{Yb}$ in the form of $\mathrm{Yb}\left(\mathrm{C}_{2} \mathrm{H}_{2} \mathrm{O}_{2}\right) \cdot 4 \mathrm{H}_{2} \mathrm{O}$ or $\mathrm{Sm}$ in the form of $\left(\mathrm{CH}_{3} \mathrm{CO}_{2}\right)_{3} \mathrm{Sm} \cdot \mathrm{xH}_{2} \mathrm{O}$ (where $\mathrm{x}$ signifies an unknown number of $\mathrm{H}_{2} \mathrm{O}$ molecules) was added to $2.54 \mathrm{~kg}$ of forage fiber. One hundred twelve grams of La in the form of $\left(\mathrm{CH}_{3} \mathrm{CO}_{2}\right)_{3} \mathrm{La} \cdot \mathrm{xH}_{2} \mathrm{O}$ was added to a total of $5.08 \mathrm{~kg}$ of mixed fiber in concentrate. The same amount of fiber in each of the forages and concentrate mixtures was intended to be labeled per gram of pure marker before starting the labeling procedure. Five different combinations of fiber residue and marker were produced in total: Yb-labeled corn silage fiber, Yb-labeled grass silage fiber, Sm-labeled corn silage fiber, Sm-labeled grass silage fiber, and La-labeled concentrate fiber. Markers were allowed to bind to fiber overnight. The labeled fiber-residues were rinsed with tap water and then soaked for $2 \mathrm{~h}$ in an acetic acid solution adjusted to $\mathrm{pH} 4$ (Ellis and Beever, 1984; Ellis et al., 1994) to re-

Table 2. Nutrient composition of the ration ingredients

\begin{tabular}{|c|c|c|c|c|c|c|}
\hline \multirow[b]{2}{*}{ Item } & \multirow{2}{*}{$\begin{array}{l}\text { Corn } \\
\text { silage }\end{array}$} & \multirow{2}{*}{$\begin{array}{l}\text { Grass } \\
\text { silage }\end{array}$} & \multicolumn{4}{|c|}{ Concentrate } \\
\hline & & & 1 & 2 & 3 & 4 \\
\hline $\mathrm{DM}$ (g/kg of feed) & 266 & 312 & 876 & 883 & 882 & 875 \\
\hline \multicolumn{7}{|l|}{ Nutrient ( $\mathrm{g} / \mathrm{kg}$ of $\mathrm{DM})$} \\
\hline Ash & 32.4 & 77.2 & 75.2 & 103 & 54.9 & 67.6 \\
\hline $\mathrm{CP}$ & 89.4 & 115 & 256 & 290 & 233 & 228 \\
\hline Starch & 239 & $\mathrm{ND}^{1}$ & 383 & 396 & 402 & 439 \\
\hline Sugar & ND & 9.8 & ND & ND & ND & ND \\
\hline $\mathrm{NDF}$ & 486 & 502 & 98.9 & 95.4 & 104 & 103 \\
\hline Indigestible NDF & 91.4 & 74.0 & 10.8 & 8.06 & 9.57 & 10.2 \\
\hline $\mathrm{pdNDF}^{2}$ & 394 & 428 & 88.1 & 89.7 & 94.3 & 93.0 \\
\hline $\mathrm{ADL}$ & 25.6 & 21.7 & 7.00 & 7.70 & 6.95 & 7.05 \\
\hline $\mathrm{IVOM}^{3}(\mathrm{~g} / \mathrm{kg}$ of $\mathrm{OM})$ & 684 & 696 & ND & ND & ND & ND \\
\hline
\end{tabular}


men liquid was collected with a suction strainer (\#RT, Bar Diamond Inc.), directly after collecting the medial rumen liquid sample. Rumen liquid $\mathrm{pH}$ was measured immediately using a pH meter (PHM 240, Hach Lange APS, Brønshøj, Denmark). Rumen liquid samples (25 $\mathrm{mL}$ ) were placed on ice until completion of 1 sample set, and then stored at $-20^{\circ} \mathrm{C}$. Sampling times were recorded.

Rumen evacuations were done on d 25 according to block at either 0800 or $1030 \mathrm{~h}$, as the study was part of a slaughter experiment. Rumen evacuations were done at the same time of the day as cows were scheduled to be slaughtered to obtain comparable rumen pool sizes. Rumen evacuations started $0.5 \mathrm{~h}$ before the assigned time. Rumen contents were separated into rumen liquid and particulate phases, as described by Tothi et al. (2003). Each phase was weighed and representative samples of $500 \mathrm{~g}$ of the 2 rumen phases were reconstituted according to their relative weight.

Daily milk yield (2 milkings) was recorded once per week and milk samples taken for fat, protein, and lactose analyses with an Msc4000 infrared analyzer (Eurofins Steins Laboratorium, Holstebro, Denmark).

\section{Chemical Analysis}

Dry matter content of the samples was determined after drying in a forced-air oven at $60^{\circ} \mathrm{C}$ for $48 \mathrm{~h}$. Samples for chemical analysis were freeze-dried and milled on a 1-mm screen in a hammer mill. Ash was determined after combustion at $525^{\circ} \mathrm{C}$ for $6 \mathrm{~h}$. ADL was determined according to ISO method 13906 (ISO, 2008). Ash-free NDF was analyzed in a Fibertec 2010 (Foss, Hillerød, Denmark) including amylase treatment according to Mertens et al. (2002). Feed $\mathrm{N}$ was analyzed by the Dumas method (Hansen, 1989) using a Vario Max CN (Elementar Analysesysteme GmbH, Hanau, Germany). Total sugar in grass silage was analyzed by the LuffSchoorl method (European Community, 2012; 71/250/ EEC). Starch was analyzed according to Bach Knudsen et al. (1987). In vitro OM digestibility followed Tilley and Terry (1963). In situ iNDF was determined after a 288 -h rumen incubation in Dacron bags with a $12-\mu \mathrm{m}$ pore size (Åkerlind et al., 2011) after grinding samples on a 1.5-mm screen using a cutter mill (Fritsch, IdarOberstein, Germany). Potentially digestible NDF was calculated as the difference between NDF and iNDF.

Chromium in rumen liquid was analyzed by atomic absorption spectroscopy at $357.9 \mathrm{~nm}$ in the supernatant after centrifugation for $10 \mathrm{~min}$ at $4,000 \times g$ at $20^{\circ} \mathrm{C}$, as in Williams et al. (1962).

Ytterbium, Sm, and La in freeze-dried feed and feces samples were simultaneously analyzed using inductively coupled plasma mass spectroscopy (XSeries ICP-MS,
Thermo Fisher Scientific Germany Ltd. \& Co. KG, Bonn, Germany).

\section{Digesta Passage Models}

Marker excretion profiles in feces were fitted to several 1-pool and 2-pool models that differed in orders of age-dependency. Model assumptions and the corresponding biological background are described in detail by Pond et al. (1988) and Ellis et al. (1994). The models used in the present study differed in the order of age-dependency related to a mixing pool and in the number of mixing pools. Discrete gamma functions (Gn) were used to model the order of age dependency. The G1 pool signifies a mixing compartment in which all particles have the same probability to escape (exponentially distributed retention time). Higher orders of age dependency (e.g., pools G2, G3, G4) signify the age-dependent distribution of retention time. The interpretation and terminology of 2-pool models followed Pond et al. (1988); that is, the first pool is the fast turnover pool with age-dependent distributions of retention times followed by a second, slow turnover pool with exponentially distributed retention times. In brief, the fractional rate of passage with age-independent, exponentially distributed retention times was termed $\mathrm{k}$, the fractional rate of passage with age-dependent, gamma-distributed retention time was termed $\lambda$, the time delay between marker dose and initial marker appearance in the feces was termed $\tau$, and the initial marker concentration in the second, turnover pool was termed $\mathrm{C}_{2}$. Additional model parameters were the mean retention time in the age-dependent (CMRT1) and age-independent (CMRT2) pools, the compartmental mean retention time (CMRT), and the total mean retention time (TMRT). Application of these models to fecal marker excretion profiles assumed no mixing pool distal to the rumen (Ellis et al., 1994).

\section{Calculations}

The SAS (SAS Institute Inc., Cary, NC) program in Moore et al. (1992) was used to fit the 3 fiber-marker excretion curves for each cow and to calculate passage kinetics based on $\mathrm{Yb}, \mathrm{Sm}$, and La excretion data in feces. Choice of 1-pool or 2-pool models was based on lowest average sum of square error (SSE). Based on the overall better fit of 2-pool models for each of the 3 markers, 2-pool models for all 3 markers were compared based on average SSE. The G3G1 and G4G1 models showed the lowest SSE and were further compared by the models' ability to fit marker excretion profiles in feces. The G4G1 model fit better than the G3G1 model to ascending, peak, and descending $\mathrm{Yb}, \mathrm{Sm}$, and $\mathrm{La}$ 
excretion data and was therefore chosen for statistical analysis of passage data.

Liquid fractional passage rate $\left(\mathbf{k p}_{\mathbf{L}}\right)$ and rumen liquid pool were calculated from $\mathrm{Cr}$ concentrations in rumen liquid for medial and ventral sampling sites within each cow separately using log-linear regression according to Grovum and Williams (1973). The algebraic calculation of TMRT (TMRT algeb ) followed Thielemans et al. (1978). Rumen evacuation-based RRT was calculated according to Robinson et al. (1987) and used iNDF intake to estimate rumen outflow. Rumen retention time was calculated as $1 / \mathrm{kp}$.

Energy-corrected milk (3.14 MJ/kg) was calculated as follows: $\mathrm{ECM}=\mathrm{kg}$ of milk $\times(0.01+0.122 \times \%$ fat in milk $+0.077 \times \%$ protein in milk $+0.053 \times \%$ lactose in milk) (Sjaunja et al., 1990).

\section{Statistical Analysis}

All statistical analyses were performed using $\mathrm{R}$ program version 2.14.0 (Crawley, 2007). Dry matter intake during restricted feeding was analyzed by a general linear model that included the fixed effects of block, forage type, $\mathrm{F}: \mathrm{C}$ ratio, and interactions between forage type and $\mathrm{F}: \mathrm{C}$ ratio. Differences in mean rumen liquid passage rates and pool sizes between ventral and medial sampling sites were tested using paired $t$-test after testing variance homogeneity. Means of the 2 sampling sites were calculated for rumen liquid passage rates and pool sizes, because medial and ventral mean values did not differ. Means of sampling sites for rumen liquid passage rates and pool sizes were analyzed by a model that included fixed effects of block, forage type, F:C ratio, interactions between forage type and $\mathrm{F}: \mathrm{C}$ ratio, and restricted DMI as covariate. Rumen evacuationbased RRT, rumen pool sizes, liquid passage rate, and best-fit rumen 2-pool model parameters were analyzed with a general linear model. The model included fixed effects of block, forage type, and $\mathrm{F}: \mathrm{C}$ ratio, the interactions between forage type and $\mathrm{F}: \mathrm{C}$ ratio, and restricted DMI as covariate.

Differences in mean CMRT between $\mathrm{Yb}$ and La and between $\mathrm{La}$ and liquid were tested using the Wilcoxon test because of variance heterogeneity $(P=0.011$ and $P=0.002$, respectively). Differences between mean TMRT $_{\text {algeb }}$ and TMRT based on marker excretion profiles were tested for $\mathrm{Yb}$ and La data using the paired $t$ test because of variance homogeneity $(P=0.064$ for $\mathrm{Yb}$ and $P=0.54$ for La). Differences in mean $\mathrm{TMRT}_{\text {algeb }}$ and TMRT based on marker excretion profiles for Sm were tested with the Wilcoxon test because of variance heterogeneity $(P=0.010)$. Differences between mean RRT based on rumen evacuation and CMRT based on marker excretion profiles were tested using the $t$-test because of variance homogeneity $(P=0.15)$.

Effects of $\mathrm{F}$ :C ratio and labeled forage fiber on TMRT were tested using $\mathrm{Yb}$ and $\mathrm{Sm}$ data together in a model that included fixed effects of block, forage, F:C ratio, restricted DMI, marker, interactions between forage and $\mathrm{F}: \mathrm{C}$ ratio, interactions between marker and forage, and between marker and $\mathrm{F}: \mathrm{C}$ ratio, and interactions between marker, forage, and $\mathrm{F}: \mathrm{C}$ ratio. Marker within cow was included as repeated measurement. All results were reported as treatment means.

\section{RESULTS}

\section{DMI and Production Parameters}

Dry matter intake was $3 \mathrm{~kg} / \mathrm{d}$ lower when rations with high F:C ratios were fed $(P<0.001$; Table 5) but did not differ between forage types $(P=0.84)$. Milk yield $(P=0.020)$, ECM $(P=0.004)$, and protein concentration $(P=0.021)$ in milk decreased with increasing F:C ratio (Table 5). Rumen liquid pool size tended to be greater for cows fed grass silage than for cows fed corn silage $(P=0.053$; Table 6$)$.

\section{Rumen Evacuation}

Rumen mean retention time of iNDF was $36.9 \pm 4.28$ $\mathrm{h}$ for corn silage-based rations and $46.9 \pm 5.68 \mathrm{~h}$ for grass silage-based rations. Despite numerical differences, differences were not significant (Table 6). Rumen NDF pool did not differ between treatments. Rumen pool size of iNDF tended to increase with increasing F:C ratio $(P=0.083$; Table 6$)$.

\section{Particle Passage Behavior}

Forage-Yb Passage Data. Passage rate of $\mathrm{Yb}$ from the age-dependent pool $(\lambda)$ was higher for corn silage-based rations than for grass silage-based rations $(P=0.033$; Table 7$)$, whereas the passage rate from the age-independent pool $(\mathrm{k})$ did not differ between rations with different forage types (Table 7). Time elapsed before first marker appearance in the feces $(\tau)$ ranged between $4 \mathrm{~h}$ for $\mathrm{G} 50$ and $7 \mathrm{~h}$ for $\mathrm{C} 75$, was higher for $\mathrm{Yb}$ in the corn silage-based ration than in the grass silagebased ration $(P=0.003)$, and tended to increase with increasing $\mathrm{F}$ : $\mathrm{C}$ ratio $(P=0.053)$. Grass silage-based rations had longer CMRT1 than corn silage-based rations $(P=0.017)$, and CMRT1 tended to be longer for higher $\mathrm{F}$ : $\mathrm{C}$ ratios in the ration $(P=0.092)$. Time spent in the age-dependent pool relative to the time spent in both compartments (CMRT1:CMRT) was higher for 
Table 5. Feed intake (restricted to $95 \%$ of ad libitum intake) and milk yield in treatments including corn silage and grass silage at forage:concentrate ratios of 50:50 and 75:25

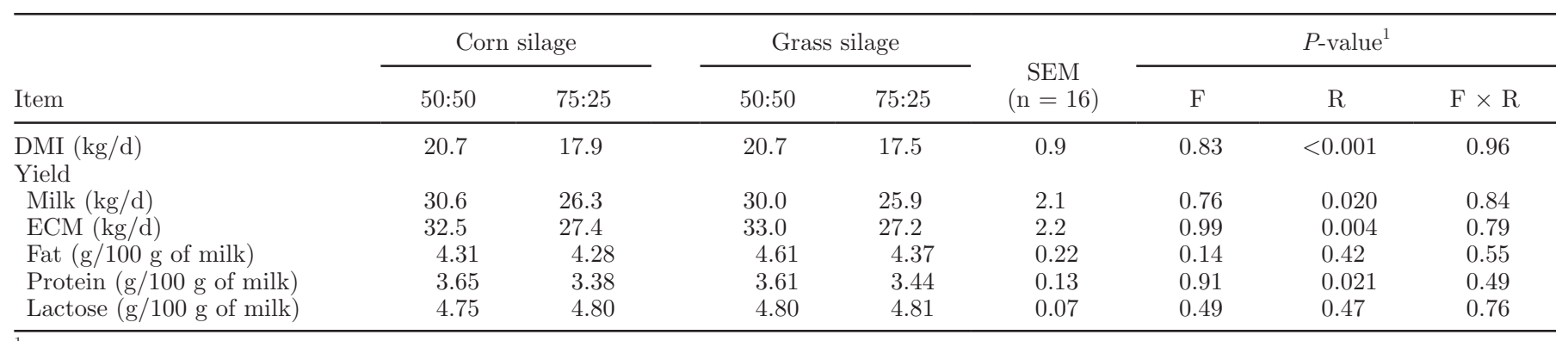

${ }^{1} \mathrm{~F}=$ forage type, $\mathrm{R}=$ forage:concentrate ratio, $\mathrm{F} \times \mathrm{R}=$ interaction between $\mathrm{F}$ and $\mathrm{R}$.

Yb-labeled grass silage fiber than for Yb-labeled corn silage fiber $(P=0.013)$. Average CMRT was $30.2 \pm$ $5.79 \mathrm{~h}$ for corn silage-based rations and $29.8 \pm 4.34 \mathrm{~h}$ for grass silage-based rations and did not differ between forage type nor between $\mathrm{F}$ :C ratios. Mean TMRT based on the G4G1 model was longer than mean $\mathrm{TMRT}_{\text {algeb }}$ $(P=0.005)$. The CMRT based on $\mathrm{Yb}$ excretion profile was shorter than rumen evacuation-based mean retention time (iNDF; $P<0.001$ ).

Forage-Sm Passage Data. Passage rate of Sm from the first, age-dependent pool $(\lambda)$ decreased with increasing $\mathrm{F}$ :C ratio $(P=0.040$; Table 8$)$ and was higher for grass silage-based rations than for corn silage-based rations $(P=0.006)$. Passage rate from the second, age-independent pool $(\mathrm{k})$ tended to be higher for corn silage-fed animals $(P=0.062)$. The CMRT1 was longer for corn silage-fed animals than for grass silage-fed animals $(P=0.005$; Table 8$)$ and tended to increase with increasing $\mathrm{F}$ : $\mathrm{C}$ ratio $(P=0.070)$, whereas CMRT2 tended to be longer for grass silage-fed animals $(P=0.060)$. The CMRT1:CMRT ratio ranged between 0.2 (G50) and 0.4 (C75) and was higher for corn silagebased rations than for grass silage-based rations $(P<$ 0.001). The CMRT1:CMRT ratio, moreover, tended to be higher for rations with high $\mathrm{F}$ :C ratio. Mean TMRT based on the G4G1 model did not differ from mean $\operatorname{TMRT}_{\text {algeb }}(P=0.24)$.

Concentrate-La Passage Data. Time elapsed before first marker appearance in feces $(\tau)$ increased with increasing $\mathrm{F}$ : $\mathrm{C}$ ratio $(P=0.019)$ and ranged between 6 (G50) and $9 \mathrm{~h}$ (C75; Table 9). Total mean retention time tended to be longer for cows fed the high $\mathrm{F}$ : C ratio $(P=0.052)$. Mean TMRT based on marker excretion profile was shorter than $\mathrm{TMRT}_{\text {algeb }}(P=0.010)$ and did not differ between forage type or $\mathrm{F}: \mathrm{C}$ ratio. Mean CMRT of La-labeled concentrate fiber was shorter than mean CMRT of Yb-labeled forage fiber $(P<0.001)$ and longer than liquid CMRT $(P<0.001)$.

Marker, Forage, and Ration Effects on TMRT. In corn silage-based rations, TMRT was higher for Yblabeled corn silage $(36.7 \pm 5.7 \mathrm{~h})$ than for Sm-labeled grass silage $(35.6 \pm 5.2 \mathrm{~h})$, tested by the model including both Yb- and Sm-based TMRT. In grass silage-based rations, TMRT was higher for Sm-labeled corn silage $(37.3 \pm 5.8 \mathrm{~h})$ than for Yb-labeled grass silage $(34.3 \pm$ $5.8 \mathrm{~h})$. Total mean retention time of $\mathrm{Yb}$ - and Sm-labeled forage fiber was not affected by marker type $(P=0.14)$, forage type $(P=0.89)$, or $\mathrm{F}$ : C ratio $(P=0.12)$. The interaction between marker and forage type, however, was highly significant $(P=0.006$; Figures $1 \mathrm{a}, \mathrm{b})$.

Table 6. Rumen retention time (RRT) of indigestible NDF (iNDF), rumen DM and fiber pool sizes based on the rumen evacuation technique, pool size of rumen liquid, and fractional rate of liquid passage $\left(\mathrm{kp}_{\mathrm{L}}\right)$ with treatments including corn silage and grass silage at forage:concentrate ratios of 50:50 and 75:25

\begin{tabular}{|c|c|c|c|c|c|c|c|c|}
\hline \multirow[b]{2}{*}{ Item } & \multicolumn{2}{|c|}{ Corn silage } & \multicolumn{2}{|c|}{ Grass silage } & \multirow{2}{*}{$\begin{array}{c}\text { SEM } \\
(\mathrm{n}=8)\end{array}$} & \multicolumn{3}{|c|}{$P$-value ${ }^{1}$} \\
\hline & $50: 50$ & $75: 25$ & $50: 50$ & $75: 25$ & & $\mathrm{~F}$ & $\mathrm{R}$ & $\mathrm{F} \times \mathrm{R}$ \\
\hline \multirow{2}{*}{\multicolumn{9}{|c|}{$\begin{array}{l}\text { iNDF } \\
\text { Rumen pool }(\mathrm{kg})\end{array}$}} \\
\hline & & & & & & & & \\
\hline DM & 9.6 & 12.6 & 12.2 & 12.2 & 2.30 & 0.43 & 0.30 & 0.52 \\
\hline iNDF & 1.37 & 2.06 & 1.75 & 2.12 & 0.26 & 0.31 & 0.083 & 0.75 \\
\hline $\operatorname{kp}_{\mathrm{L}}\left(\mathrm{h}^{-1}\right)$ & 0.145 & 0.145 & 0.170 & 0.157 & 0.006 & 0.13 & 0.47 & 0.53 \\
\hline
\end{tabular}

${ }^{1} \mathrm{~F}=$ forage type, $\mathrm{R}=$ forage:concentrate ratio, $\mathrm{F} \times \mathrm{R}=$ interaction between $\mathrm{F}$ and $\mathrm{R}$. 
Table 7. Passage kinetics of Yb-labeled corn silage and grass silage fiber administered to cows fed the respective forage; parameters are based on the G4G1 model (a 2-pool model consisting of an age-dependent and an age-independent pool), with treatments including corn silage and grass silage at forage:concentrate ratios of 50:50 and 75:25

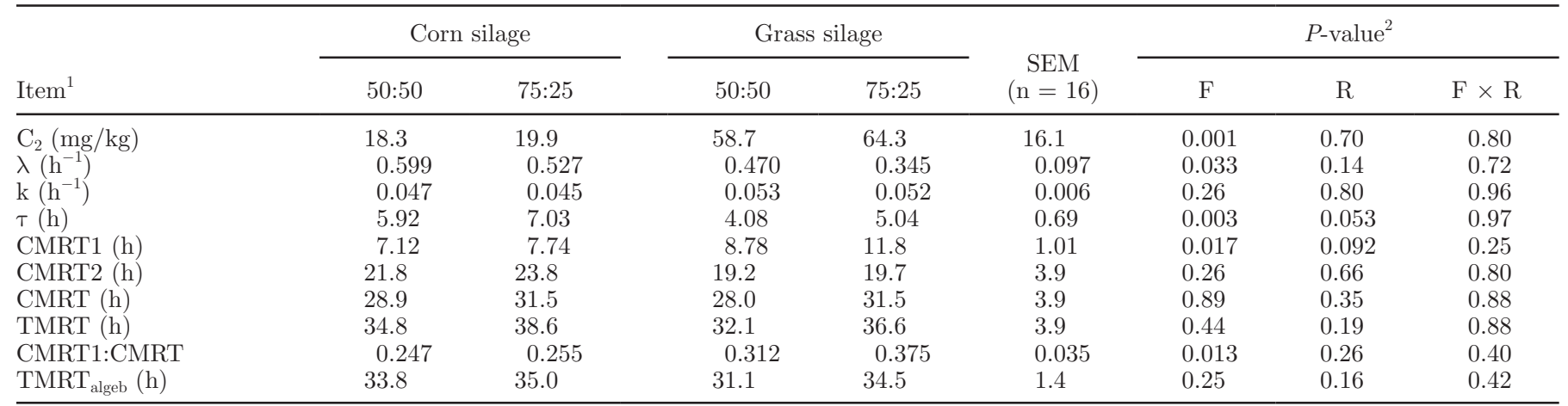

${ }^{1} \mathrm{C}_{2}=$ initial marker concentration in the second, age-independent pool; $\lambda=$ fractional rate of passage from the age-dependent pool in a 2 -pool model; $\mathrm{k}=$ fractional rate of passage from the age-independent pool in a 2-pool model; $\tau=$ time delay, time elapsed before first appearance of marker at the sampling site; CMRT1 = mean retention time in the age-dependent pool; CMRT2 = mean retention time in the age-independent pool; $\mathrm{CMRT}=$ mean retention time of marker in both pools, CMRT $=$ CMRT1 + CMRT2; TMRT $=$ total mean retention time, TMRT $=$ $\mathrm{CMRT}+\tau$; and $\mathrm{TMRT}_{\text {algeb }}=$ total mean retention time calculated algebraically (Thielemans et al., 1978).

${ }^{2} \mathrm{~F}=$ forage type, $\mathrm{R}=$ forage:concentrate ratio, $\mathrm{F} \times \mathrm{R}=$ interaction between $\mathrm{F}$ and $\mathrm{R}$.

\section{DISCUSSION}

\section{Rumen Mean Retention Time Estimated by Rumen Evacuation}

Effects of Forage Type on RRT. The numerically longer RRT of grass silage-based rations (46.9 \pm $5.68 \mathrm{~h}$ ) compared with corn silage-based rations (36.9 $\pm 4.28 \mathrm{~h}$ ) was in accordance with Lund (2002), who found a mean RRT of $56.9 \mathrm{~h}$ for grass silage and $44.4 \mathrm{~h}$ for corn silage in dry cows fed forage only. Differences between corn and grass silages were not statistically significant in Lund (2002) either. The longer RRT for both rations in Lund (2002) compared with our results is probably because of the higher feeding level of cows in the present study. The higher RRT for rations based on grass silage compared with those based on corn silage is probably due to morphological differences between forage types that influence the ease and pattern of particle breakdown (Wilson and Kennedy, 1996). Bruining et al. (1998) observed a higher proportion of large particles in rumen particulate DM after feeding grass silage compared with corn or lucerne silage, suggesting that particle breakdown to the same final particle size requires more time for grass silage than for corn silage particles. Grass silage, moreover, was observed to break into long, thin particles during grinding or chewing;

Table 8. Passage kinetics of Sm-labeled corn silage or grass silage fiber administered to cows fed the opposite forage; parameters are based on the G4G1 model (a 2-pool model consisting of an age-dependent and an age-independent pool), with treatments including corn silage and grass silage at forage:concentrate ratios of 50:50 and 75:25

\begin{tabular}{|c|c|c|c|c|c|c|c|c|}
\hline Item $^{1}$ & \multicolumn{2}{|c|}{ Corn silage } & \multicolumn{2}{|c|}{ Grass silage } & $\begin{array}{c}\text { SEM } \\
(\mathrm{n}=16)\end{array}$ & \multicolumn{3}{|c|}{$P$-value ${ }^{2}$} \\
\hline $\mathrm{C}_{2}(\mathrm{mg} / \mathrm{kg})$ & 54.8 & 58.8 & 15.6 & 15.7 & 13.8 & $<0.001$ & 0.79 & 0.89 \\
\hline $\mathrm{k}\left(\mathrm{h}^{-1}\right)$ & 0.058 & 0.058 & 0.044 & 0.040 & 0.009 & 0.062 & 0.77 & 0.77 \\
\hline$\tau(h)$ & 5.13 & 5.91 & 5.01 & 5.74 & 1.3 & 0.86 & 0.37 & 0.96 \\
\hline CMRT1 (h) & 10.7 & 12.6 & 6.26 & 8.93 & 1.5 & 0.005 & 0.070 & 0.74 \\
\hline CMRT1:CMRT & 0.372 & 0.411 & 0.215 & 0.269 & 0.042 & $<0.001$ & 0.083 & 0.80 \\
\hline $\mathrm{TMRT}_{\text {algeb }}(\mathrm{h})$ & 33.6 & 35.0 & 32.1 & 35.3 & 1.5 & 0.71 & 0.18 & 0.55 \\
\hline
\end{tabular}

${ }^{1} \mathrm{C}_{2}=$ initial marker concentration in the second, age-independent pool; $\lambda=$ fractional rate of passage from the age-dependent pool in a 2-pool model; $\mathrm{k}=$ fractional rate of passage from the age-independent pool in a 2-pool model; $\tau=$ time delay, time elapsed before first appearance of marker at the sampling site; CMRT1 = mean retention time in the age-dependent pool; CMRT2 = mean retention time in the age-independent pool; $\mathrm{CMRT}=$ mean retention time of marker in both pools, $\mathrm{CMRT}=\mathrm{CMRT} 1+\mathrm{CMRT} 2$; TMRT $=$ total mean retention time, TMRT $=$ $\mathrm{CMRT}+\tau$; and $\mathrm{TMRT}_{\text {algeb }}=$ total mean retention time calculated algebraically (Thielemans et al., 1978).

${ }^{2} \mathrm{~F}=$ forage type, $\mathrm{R}=$ forage:concentrate ratio, $\mathrm{F} \times \mathrm{R}=$ interaction between $\mathrm{F}$ and $\mathrm{R}$. 
Table 9. Passage kinetics of La-labeled concentrate fiber; parameters are based on the G4G1 model (a 2-pool model consisting of an agedependent and an age-independent pool), with treatments including corn silage and grass silage at forage:concentrate ratios of 50:50 and 75:25

\begin{tabular}{|c|c|c|c|c|c|c|c|c|}
\hline Item $^{1}$ & \multicolumn{2}{|c|}{ Corn silage } & \multicolumn{2}{|c|}{ Grass silage } & $\begin{array}{c}\text { SEM } \\
(\mathrm{n}=16)\end{array}$ & \multicolumn{3}{|c|}{$P$-value ${ }^{2}$} \\
\hline $\mathrm{k}\left(\mathrm{h}^{-1}\right)$ & 0.083 & 0.078 & 0.082 & 0.073 & 0.092 & 0.65 & 0.38 & 0.80 \\
\hline$\tau(h)$ & 6.57 & 8.79 & 5.57 & 7.84 & 1.1 & 0.24 & 0.019 & 0.90 \\
\hline CMRT1 (h) & 6.2 & 5.4 & 5.2 & 5.7 & 1.0 & 0.74 & 0.90 & 0.54 \\
\hline TMRT (h) & 25.0 & 27.7 & 23.2 & 27.7 & 2.0 & 0.59 & 0.052 & 0.55 \\
\hline CMRT1:CMRT & 0.334 & 0.292 & 0.290 & 0.294 & 0.056 & 0.67 & 0.65 & 0.73 \\
\hline TMRT $_{\text {algeb }}(\mathrm{h})$ & 26.4 & 27.7 & 24.2 & 27.7 & 1.3 & 0.37 & 0.11 & 0.35 \\
\hline
\end{tabular}

${ }^{1} \mathrm{C}_{2}=$ initial marker concentration in the second, age-independent pool; $\lambda=$ fractional rate of passage from the age-dependent pool in a 2 -pool model; $\mathrm{k}=$ fractional rate of passage from the age-independent pool in a 2-pool model; $\tau=$ time delay, time elapsed before first appearance of marker at the sampling site; CMRT1 = mean retention time in the age-dependent pool; CMRT2 = mean retention time in the age-independent pool; $\mathrm{CMRT}=$ mean retention time of marker in both pools, CMRT $=$ CMRT1 + CMRT2; TMRT $=$ total mean retention time, TMRT $=$ $\mathrm{CMRT}+\tau$; and $\mathrm{TMRT}_{\text {algeb }}=$ total mean retention time calculated algebraically (Thielemans et al., 1978).

${ }^{2} \mathrm{~F}=$ forage type, $\mathrm{R}=$ forage:concentrate ratio, $\mathrm{F} \times \mathrm{R}=$ interaction between $\mathrm{F}$ and $\mathrm{R}$.

these particles form a dense rumen mat that has a large capacity to entrap small particles (Mertens, 2002). Corn silage, in contrast, tends to break into cuboidal particles that are thought to form a less dense rumen mat that entraps fewer small particles than the rumen mat formed by grass silage rations (Mertens, 2002).

Effects of F:C Ratio on Particulate and Liquid Retention Times. The F:C ratio in the ration did not systematically alter RRT of grass silage- and corn silage-based rations based on the rumen evacuation method and iNDF flow. For grass silage rations, an increased $\mathrm{F}: \mathrm{C}$ ratio numerically increased $(+7 \mathrm{~h}) \mathrm{RRT}$, whereas for corn silage rations, an increased $\mathrm{F}$ : $\mathrm{C}$ ratio numerically decreased RRT ( $-3 \mathrm{~h})$. Information on the effect of $\mathrm{F}$ : $\mathrm{C}$ ratio in the literature is often confounded with feed intake level or lactation stage. Stensig et al. (1998) reported a significant effect of supplement source (pure wheat starch vs pure sucrose) on RRT of iNDF based on rumen evacuations but no significant effect of $\mathrm{F}: \mathrm{C}$ ratio (20 vs. $30 \%$ concentrate in ration $\mathrm{DM})$. Comparable to our study, numerical differences in RRT between rations with different $\mathrm{F}$ : $\mathrm{C}$ ratios were observed in Stensig et al. (1998).

Forage:concentrate ratio did not affect rumen liquid pool and liquid passage rate in the present study. Rumen liquid pool, however, increased numerically $(+13$
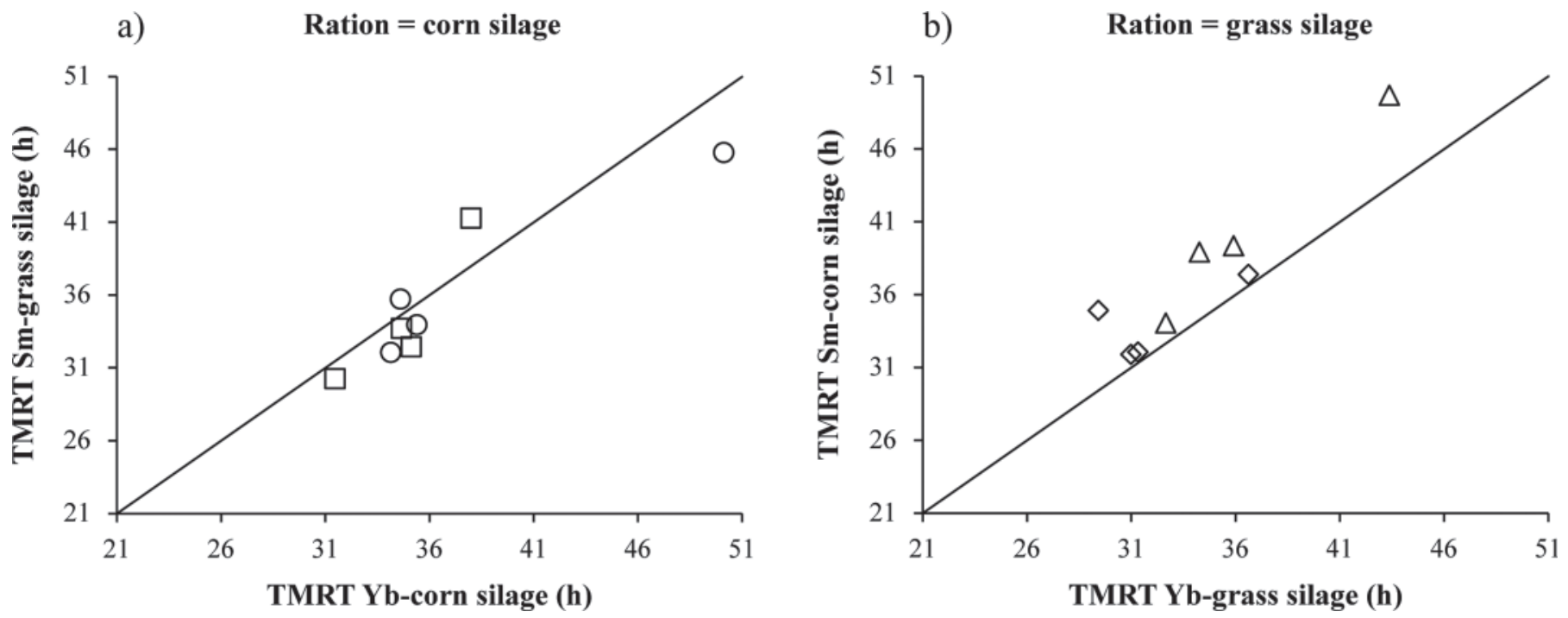

Figure 1. (a) Total mean retention time (TMRT) of ytterbium (Yb)-labeled corn silage fiber and samarium (Sm)-labeled grass silage fiber for cows fed corn silage-based rations; (b) TMRT of Yb-labeled grass silage fiber and Sm-labeled corn silage fiber for cows fed grass silage-based rations. $\Delta=$ grass silage fed in the ration with 75:25 forage:concentrate (F:C) ratio, $\diamond=$ grass silage fed in the ration with 50:50 F:C ratio, 0 $=$ corn silage fed in the ration with 75:25 F:C ratio, and $\square=$ corn silage fed in the ration with 50:50 F:C ratio. The line is $\mathrm{y}=\mathrm{x}$. 
L) with increased F:C ratio for grass silage- and corn silage-based rations, probably because rations with a higher forage proportion are chewed and salivated more intensely than those with lower forage proportions. Poore et al. (1990), in contrast, observed no effects of $\mathrm{F}: \mathrm{C}$ ratio on rumen liquid pool using CoEDTA as marker for rations containing 30,60, and $90 \%$ concentrate. Colucci et al. (1990) reported higher liquid passage rates from the rumen with increasing $\mathrm{F}$ : $\mathrm{C}$ ratio for cows and sheep fed at maintenance level, whereas liquid passage rates did not change with $\mathrm{F}$ : $\mathrm{C}$ ratio at ad libitum intake. Rumen liquid pool increased linearly with increasing $\mathrm{F}$ :C ratio (Colucci et al., 1990) in line with our findings.

\section{Mean Retention Time Estimated by Marker Excretion Profiles in Feces}

A longer retention time of $\mathrm{Yb}$ in the second pool compared with the first pool was shown for both forage types. This indicates that the age-independent passage of aged particles out of the rumen, not the release of particles from the first pool, was the limiting step for the escape of labeled fiber particles from the rumen for corn silage, grass silage, and concentrates. This supports earlier findings (Wylie et al., 2000; Huhtanen et al., 2006; Lund et al., 2006).

Differences Between Yb-Labeled Corn Silage Fiber and Yb-Labeled Grass Silage Fiber. Ytterbium-labeled corn silage fiber was retained for less time than Yb-labeled grass silage fiber before particles were released from the first pool, consistent with Lund et al. (2006). Retention time in the second pool, which contains particles that have undergone hydration, comminution, and rumination processes, did not differ between Yb-labeled forage types. This implies that the release of aged, escapable fiber particles is independent of their origin. Differences in CMRT1, but not in CMRT2, between labeled masticated hay particles and labeled small fecal particles were found by $\mathrm{Wy}$ lie et al. (2000). This indicates that intrinsic particle characteristics of the investigated feedstuffs predominantly affect the passage out of the first, age-dependent pool, in which processes altering particle structure and buoyancy appear as suggested by Kennedy and Murphy (1988). The influence of the particle's resistance to comminution and particle size reduction on passage kinetics is highlighted by the shorter CMRT1 of Lalabeled concentrate particles compared with Yb-labeled forage particles found in the present study.

The shorter CMRT1 of Yb-labeled corn silage fiber compared with Yb-labeled grass silage fiber could be due to smaller particle size (chopping length) of corn silage than grass silage. Poppi et al. (1980) showed that passage rate from the rumen decreases with increasing particle size, and Huhtanen et al. (2006) suggested that the probability for particle escape from the rumen decreases with increasing particle length and width. Huhtanen et al. (2006), however, suggested that within the range used on farm, effects of chopping length on intrinsic passage rates are rather small. Shorter retention time of Yb-labeled corn silage than Yb-labeled grass silage fiber in the first rumen pool could be due to higher concentrations of pdNDF in grass silage fiber than in corn silage fiber, as pdNDF was shown to be selectively retained in the rumen compared with iNDF (Tamminga et al., 1989; Lund et al., 2007). Wilson and Kennedy (1996) found that high-quality temperate grass leaves were easily digested by microbes and had a fast initial breakdown of epidermal and vascular structures compared with tropical grass leaves. Based on intrinsic feed characteristics, fiber CMRT1 was therefore expected to be longer for corn silage (tropical grass) than grass silage (temperate grass).

$\boldsymbol{F}: \boldsymbol{C}$ Ratio. The F:C ratio did not affect CMRT of Yb-labeled forage and La-labeled concentrate fiber, which is in accordance with Stensig et al. (1998), who did not find an effect of $\mathrm{F}: \mathrm{C}$ ratio on CMRT of $\mathrm{Yb}-$ labeled grass silage. Lund (2002), however, reported longer CMRT of various Yb-labeled forage fiber for unsupplemented compared with supplemented rations. Colucci et al. (1982) reported shorter CMRT for Crmordanted soybean meal, corn grain, corn silage, and hay crop silage cell walls with increased $\mathrm{F}$ : $\mathrm{C}$ ratio, with more pronounced effects at lower feed intake compared with high feed intake. Colucci et al. (1990), in contrast, observed shorter CMRT of Cr-labeled alfalfa cell walls with increasing $\mathrm{F}$ :C ratio at low feed intakes for sheep and cows, whereas at high intake, CMRT was only numerically decreased. Chromium-mordanted soybean meal cell walls showed shorter CMRT with increasing F:C ratio for both intake levels and species. Poore et al. (1990), using rare-earth markers, observed no change in CMRT between rations with 30 and $60 \%$ concentrate for all forages but retention times of wheat straw and alfalfa hay increased for the $90 \%$ concentrate ration compared with the $60 \%$ concentrate ration. Variations in $\mathrm{F}: \mathrm{C}$ ratio are thought to have a greater effect on retention time of low-quality forage compared with grain or high-quality forage (Poore et al., 1990). Contradictory effects of $\mathrm{F}: \mathrm{C}$ ratio on CMRT between studies are probably caused by marker type, labeled feed fraction, dosing, and sampling site and procedure. The effect of F:C ratio on CMRT depends on feedstuff type, which highlights the importance of intrinsic factors on the retention time of fiber. 


\section{Marker Choice}

Rare earths and $\mathrm{Cr}$ are the most frequently used external markers to study passage kinetics of particulate matter. Chromium has been criticized for altering physical characteristics and the digestibility of labeled feedstuffs (Ehle et al., 1984), and rare earths have been observed to migrate to rumen liquid (Combs and Satter, 1992) and to mainly bind to small particles (Siddons et al., 1985). Detachment of markers from labeled feedstuffs, however, is inevitable as part of the labeled feedstuffs is digested. To prevent marker migration, we followed the labeling procedure in Ellis et al. (1994), which attempts to remove loosely bound markers by acidifying to $\mathrm{pH} 4$ and by applying rare-earth markers to the fiber fraction of feedstuffs, as the binding affinity of rare earths was reported to be highest to fiber (Van Soest, 1994). Huhtanen and Kukkonen (1995) highlighted the differences between $\mathrm{Cr}$ and $\mathrm{Yb}$ and found $\mathrm{Yb}$ to be superior in describing the passage behavior of NDF and pdNDF, whereas Cr more accurately described the passage of iNDF. To minimize marker effects on the measured passage data, all feedstuffs were labeled with rare-earth elements with similar binding affinity and migration potential (Van Soest, 1994). Markers were chosen based on their strong binding affinity to fiber (Van Soest, 1994) and because reliable results have been reported in the literature (Ellis et al., 2002; Ahvenjärvi et al., 2010).

\section{Model Choice}

Besides very low estimates for fiber CMRT, low time delay values resulted from the use of the G4G1 model to fit Yb-excretion profiles. Comparison of G4G1 estimated time delay values $(5 \mathrm{~h}$ as mean for markers and rations) with the time of first marker appearance in feces ( $8 \mathrm{~h}$, data not shown) suggests a minor underestimation of time delay when using the G4G1 model, which was also observed by Huhtanen and Kukkonen (1995). The time point of first analytically detected marker appearance in feces, however, is overestimated appearance as fecal samples were taken every $4 \mathrm{~h}$, so that the true time delay could range between 4 and 8 $\mathrm{h}$. Lower time delay values in the present study than those reported in the literature (around 8 h, Ellis et al., 1994; Huhtanen and Kukkonen, 1995) were probably due to the higher DMI of cows used in the present study. The G4G1 model was evaluated as the best-fit model for the present marker excretion profiles as it fitted ascending, descending, and peak marker concentrations for all markers and cows best, even though the time delay values ( $6 \mathrm{~h}$, data not shown) derived from the G3G1 model were closer to the observed first marker appearance in feces. Increasing the order of age dependency in the age-dependent pool increases the retention time in the faster turnover pool (CMRT1) at the expense of the time delay (Pond et al., 1988; Moore et al., 1992; Huhtanen and Kukkonen, 1995). Rather, the distribution of marker retention time between time delay and CMRT1 may reflect the model behavior than true biological differences, as time delays for liquid were similar to those for particulate matter (Huhtanen and Kukkonen, 1995). Algebraically calculated TMRT was shorter than G4G1-derived TMRT for forage fiber, in line with Lund et al. (2006).

\section{Comparison of Rumen Evacuation and Marker Excretion Profiles to Estimate Rumen Mean Retention Time}

Ytterbium-labeled forage fiber CMRT based on the G4G1 model averaged $30 \mathrm{~h}$ for corn silage and grass silage, whereas rumen evacuation-based RRT of iNDF averaged $37 \mathrm{~h}$ for corn silage-based rations and $47 \mathrm{~h}$ for grass silage-based rations. Shorter CMRT using marker excretion profiles fitted to rumen pool models compared with RRT based on rumen evacuation have consistently been reported in the literature (Ellis et al., 1994; Huhtanen and Kukkonen, 1995; Lund, 2002). Rumen evacuation-based retention times in the present study yielded biologically more realistic RRT, which compare (even though RRT in the present study were lower) with reported RRT in the literature (Ellis et al., 1994; Huhtanen and Kukkonen, 1995; Lund, 2002). The use of lactating dairy cows with a high feed intake in the present study explains the lower rumen evacuation-based RRT than reported in the literature for animals with lower feed intake. Lund (2002) suggested that the rumen evacuation technique estimates retention time accurately, whereas the marker approach can be used to distribute RRT between the 2 pools in a 2 -pool model when absolute RRT values are known from rumen evacuation studies.

Comparing differences in retention times between corn silage and grass silage fiber derived by either of the methods revealed that CMRT based on Ybexcretion profiles in feces fitted to the G4G1 model was similar for grass silage fiber $(29.8 \mathrm{~h})$ and corn silage fiber $(30.2 \mathrm{~h})$, whereas the rumen evacuation technique yielded numerically much longer $(+10 \mathrm{~h}) \mathrm{RRT}$ for grass silage-based rations compared with corn silage-based rations. Shorter RRT of alfalfa and corn silage compared with those of grass silage were also observed in a meta-analysis by Krizsan et al. (2010) using rumen evacuation results. Higher range in absolute RRT and 
a different ranking of forages were also found by Lund (2002) using the rumen evacuation technique and iNDF flow compared with $\mathrm{Yb}$ excretion profiles in feces.

The discrepancy between the methods could, moreover, be caused by differences in model assumptions. Passage kinetics based on the rumen evacuation method and iNDF flow are determined for the total ration, and an allocation of passage kinetics to one specific feedstuff is not possible (Stensig et al., 1998). Ytterbium excretion profiles in feces fitted to the 2-pool (G4G1) model, in contrast, estimate the passage of one specific feedstuff in the ration but describe the behavior of the marker itself and not necessarily the behavior of the labeled nutrient in question. Ytterbium-based CMRT, moreover, not only reflects retention time in the rumen, but also includes retention time in the hindgut (about $10 \%$ of total-tract retention time; Ellis et al., 2002).

Differences in characteristics of unlabeled and labeled feedstuffs could have caused the contradictory results in RRT between the 2 methods used. The RRT estimated with the rumen evacuation technique is that of the consumed grass and corn silage iNDF in combination with the ration, whereas the marker approach estimates the passage behavior of labeled feedstuff fiber that had undergone boiling, labeling, and acidifying processes and had a lower DM content than unlabeled feedstuffs (data not shown).

\section{Marker, Forage, and Ration Effects on TMRT}

Total mean retention time, rather than CMRT, was used to study the relative importance of intrinsic (forage type) and extrinsic (ration composition) factors on fiber retention time. Compartmental mean retention time depends on the pool model chosen to fit marker excretion profiles, whereas similar estimates of TMRT independent of the 2-pool model used were reported by Ellis et al. (1994).

The forage fed in the ration was always labeled with $\mathrm{Yb}$, whereas the forage not fed in the ration was always labeled with $\mathrm{Sm}$ to allow analysis of main effects of forage type fed in the ration with $\mathrm{Yb}$ marker excretion profiles. To distinguish effects of forage type from effects of ration composition on the retention time of fiber, marker excretion profiles of Yb-labeled fiber of the same forage as fed in the ration and Sm-labeled fiber of the forage not fed in the ration were analyzed together. As illustrated in Figure 1, in corn silage-based rations, TMRT was higher for Yb-labeled corn silage fiber (37 h) than for Sm-labeled grass silage fiber ( $36 \mathrm{~h}$ ). In grass silage-based rations, TMRT was higher for Sm-labeled corn silage fiber $(37 \mathrm{~h})$ than for Yb-labeled grass silage fiber $(34 \mathrm{~h})$. The model used for analysis allowed allocation of observed effects to marker, forage, or ration composition. A significant interaction between marker type and forage type on the TMRT of labeled forage fiber was found but no significant effect of marker type. The significant interaction between marker and forage together with the nonsignificant effect of marker type revealed that the consistently longer TMRT of labeled corn silage in both rations was solely caused by forage type, not by marker type. Total mean retention time of labeled forage fiber in the present study was therefore limited by intrinsic effects of forage type rather than by extrinsic effects of ration composition. Krizsan et al. (2010) concluded, in accordance with our findings, that intrinsic feed characteristics affect passage kinetics of particulate matter in ruminants and should be included in feed evaluation systems. In contrast to our findings, Vega and Poppi (1997) concluded that neither extent of digestion nor forage type affects the passage rate of labeled DM.

The nonsignificant effect of marker type, moreover, indicated that the rare-earth markers $\mathrm{Yb}$ and $\mathrm{Sm}$ behaved similarly whether bound to corn or to grass silage fiber. Ellis et al. (1994) compiled data from the literature and did not find significant differences in passage rates between the rare-earth markers $\mathrm{Yb}, \mathrm{Sm}$, and La, in line with our results.

\section{Passage Behavior of Forage and Concentrate Fiber and Rumen Liquid}

Lanthanum-labeled concentrate fiber remained numerically longer in the second age-independent pool than in the first age-dependent pool, independent of the ration composition. Lanthanum-labeled concentrate fiber CMRT, moreover, was not affected by ration composition, which was comparable to that of forage fiber. Longer CMRT of Yb-labeled forage fiber than of La-labeled concentrate fiber is consistent with previous findings (Colucci et al., 1982; Ellis et al., 2002) and could be due to smaller particle size and higher specific gravity of concentrate particles (Huhtanen et al., 2006). Liquid CMRT was, as expected, shorter than CMRT of Yb-labeled forage and La-labeled concentrate fiber, and sampling either the ventral or medial rumen did not affect liquid passage estimates. Rumen retention time estimates of rumen liquid are therefore independent of the sampling site.

\section{CONCLUSIONS}

Forage type itself, rather than ration composition, seemed to determine total-tract retention time of forage fiber, as labeled corn silage fiber remained longer in the digestive tract than did labeled grass silage fiber, independent of ration composition or rare-earth marker. 
Forage to concentrate ratio did not affect rumen passage kinetics of particulate matter and rumen liquid. The rumen evacuation technique based on iNDF flow detected a numerically longer rumen retention time of rations based on grass silage compared with corn silage, whereas $\mathrm{Yb}$ applied to grass and corn silage fiber did not detect differences in retention times between forage types.

\section{ACKNOWLEDGMENTS}

The authors gratefully acknowledge A. C. Storm, N. B. Kristensen, T. Hvelplund, and M. Larsen from the Department of Animal Science (Aarhus University, Tjele, Denmark), P. Huhtanen from the Department of Agricultural Research for Northern Sweden (Swedish University of Agricultural Sciences, Umeå, Sweden), and K.-H. Südekum from the Institute of Animal Science (University of Bonn, Germany) for their advice and comments to the experimental design and marker preparation. We thank T. N. Jakobsen, B. H. Løth, and staff from Department of Animal Science (Aarhus University) for their skillful practical assistance. The project was funded by Mælkeafgiftsfonden and Aarhus University.

\section{REFERENCES}

Ahvenjärvi, S., A. Vanhatalo, T. Stefanski, and P. Huhtanen. 2010. Fibre digestion in different segments of the digestive tract of dairy cows fed grass silage based diets. Pages 199-201 in Proc. 1st Nordic Feed Science Conference, Uppsala. SLU Repro, Uppsala, Sweden.

Åkerlind, M., M. R. Weisbjerg, T. Eriksson, R. Tøgersen, P. Udén, B. L. Ólafsson, O. M. Harstad, and H. Volden. 2011. Feed analyses and digestion methods. Pages 41-54 in NorFor-The Nordic Feed Evaluation System. H. Volden, ed. Wageningen Academic Publishers, Wageningen, the Netherlands.

Allen, M. S., and D. R. Mertens. 1988. Evaluating constraints on fiber digestion by rumen microbes. J. Nutr. 118:261-270.

Bach Knudsen, K. E., P. Åman, and B. O. Eggum. 1987. Nutritive value of Danish-grown barley varieties: I. Carbohydrates and other major constituents. J. Cereal Sci. 6:173-186.

Binnerts, W. T., A. T. Vantkloo, and A. M. Frens. 1968. Soluble chromium indicator measured by atomic absorption in digestion experiments. Vet. Rec. 82:470.

Bruining, M., R. Bakker, J. van Bruchem, and S. Tamminga. 1998. Rumen digesta kinetics in dairy cows fed grass, maize and alfalfa silage. 1. Comparison of conventional, steady-state and dynamic methods to estimate microbial degradation, comminution and passage of particles. Anim. Feed Sci. Technol. 73:37-58.

Colucci, P. E., L. E. Chase, and P. J. Van Soest. 1982. Feed-intake, apparent ration digestibility, and rate of particulate passage in dairy cattle. J. Dairy Sci. 65:1445-1456.

Colucci, P. E., G. K. Macleod, W. L. Grovum, I. McMillan, and D. J. Barney. 1990. Digesta kinetics in sheep and cattle fed diets with different forage to concentrate ratios at high and low intakes. J. Dairy Sci. 73:2143-2156.

Combs, D. K., and L. D. Satter. 1992. Determination of markers in digesta and feces by direct current plasma emission spectroscopy. J. Dairy Sci. 75:2176-2183.

Crawley, M. J. 2007. The R Book. John Wiley \& Sons Ltd., West Sussex, UK. Accessed Dec. 6, 2011. http://www.r-project.org.
Ehle, F. R., F. Bas, B. Barno, R. Martin, and F. Leone. 1984. Particulate rumen turnover rate measurement as influenced by density of passage marker. J. Dairy Sci. 67:2910-2913.

Ellis, W. C., and D. E. Beever. 1984. Methods for binding rare earths to specific feed particles. Pages 154-165 in Techniques in Particle Size Analysis of Feed and Digesta in Ruminants. P. M. Kennedy, ed. Can. Soc. Anim. Sci., Edmonton, Alberta, Canada.

Ellis, W. C., and J. E. Huston. 1968. ${ }^{144} \mathrm{Ce}^{-144} \mathrm{Pr}$ as a particulate digesta flow marker in ruminants. J. Nutr. 95:67-78.

Ellis, W. C., J. H. Matis, T. M. Hill, and M. R. Murphy. 1994. Methodology for estimating digestion and passage kinetics of forages. Pages 682-756 in Forage Quality, Evaluation and Utilization. G. C. Fahey Jr., M. Collins, D. R. Mertens, and L. E. Moser, ed. Am. Soc. Agron., Crop Sci. Soc. Am., Soil Sci. Soc. Am., Madison, WI.

Ellis, W. C., M. J. Wylie, and J. H. Matis. 2002. Validity of specifically applied rare earth elements and compartmental models for estimating flux of undigested plant tissue residues through the gastrointestinal tract of ruminants. J. Anim. Sci. 80:2753-2758.

European Community. 2012. First commission directive of 15 June 1971 establishing Community methods of analysis for the official control of feeding-stuffs (71/250/EEC). Accessed May 15, 2012. http:// eur-lex.europa.eu/LexUriServ/LexUriServ.do?uri=DD:I:1971_ II:31971L0250:EN:PDF.

Fox, D. G., L. O. Tedeschi, T. P. Tylutki, J. B. Russell, M. E. Van Amburgh, L. E. Chase, A. N. Pell, and T. R. Overton. 2004. The Cornell Net Carbohydrate and Protein System model for evaluating herd nutrition and nutrient excretion. Anim. Feed Sci. Technol. 12:29-78.

Grovum, W. L., and V. J. Williams. 1973. Rate of passage of digesta in sheep. Br. J. Nutr. 30:313-329.

Hansen, B. 1989. Determination of nitrogen as elementary N, an alternative to Kjeldahl. Acta Agric. Scand. 39:113-118.

Huhtanen, P., S. Ahvenjärvi, M. R. Weisbjerg, and P. Nørgaard. 2006. Digestion and passage of fibre in ruminants. Pages 87-135 in $\mathrm{Ru}-$ minant Physiology: Digestion, Metabolism and Impact of Nutrition on Gene Expression, Immunology and Stress. K. Sejrsen, T. Hvelplund and M. O. Nielsen, ed. Wageningen Press, Wageningen, the Netherlands.

Huhtanen, P., and S. Jaakkola. 1993. The effects of forage preservation method and proportion of concentrate on digestion of cell-wall carbohydrates and rumen digesta pool size in cattle. Grass Forage Sci. 48:155-165.

Huhtanen, P., and U. Kukkonen. 1995. Comparison of methods, markers, sampling sites and models for estimating digesta passage kinetics in cattle fed at 2 levels of intake. Anim. Feed Sci. Technol. $52: 141-158$.

ISO. 2008. Animal feeding stuffs: Determination of acid detergent fibre (ADF) and acid detergent lignin (ADL) contents. ISO 13906:2008 International Organization for Standardization, Geneva, Switzerland.

Kennedy, P. M., and M. R. Murphy. 1988. The nutritional implications of differential passage of particles through the ruminant alimentary tract. Nutr. Res. Rev. 1:189-208.

Krizsan. S. J., S. Ahvenjärvi, and P. Huhtanen. 2010. A meta-analysis of passage rate estimated by rumen evacuation with cattle and evaluation of passage rate prediction models. J. Dairy Sci. 93:5890-5901.

Kuoppala, K., S. Ahvenjärvi, M. Rinne, and A. Vanhatalo. 2009. Effects of feeding grass or red clover silage cut at two maturity stages in dairy cows. 2. Dry matter intake and cell wall digestion kinetics. J. Dairy Sci. 92:5634-5644.

Kuoppala, K., M. Rinne, S. Ahvenjärvi, J. Nousiainen, and P. Huhtanen. 2010. The effect of harvesting strategy of grass silage on digestion and nutrient supply in dairy cows. J. Dairy Sci. 93:3253-3263

Lund, P. 2002. The effect of forage type on passage kinetics and digestibility of fibre in dairy cows. PhD Thesis. The Royal Veterinary and Agricultural University, Copenhagen, Denmark.

Lund, P., M. R. Weisbjerg, and T. Hvelplund. 2006. Passage kinetics of fibre in dairy cows obtained from duodenal and faecal ytter- 
bium excretion-Effect of forage type. Anim. Feed Sci. Technol. 128:229-252.

Lund, P., M. R. Weisbjerg, and T. Hvelplund. 2007. Digestible NDF is selectively retained in the rumen of dairy cows compared to indigestible NDF. Anim. Feed Sci. Technol. 134:1-17.

Mertens, D. R. 2002. Fiber: Measuring, modeling and feeding. Pages 1-18 in Proc. Cornell Nutrition Conference for Feed Manufacturers. Cornell University, Ithaca, NY.

Mertens, D. R., M. Allen, J. Carmany, J. Clegg, A. Davidowicz, M. Drouches, K. Frank, D. Gambin, M. Garkie, B. Gildemeister, D. Jeffress, C. S. Jeon, D. Jones, D. Kaplan, G. N. Kim, S. Kobata, D. Main, X. Moua, B. Paul, J. Robertson, D. Taysom, N. Thiex, J. Williams, and M. Wolf. 2002. Gravimetric determination of amylase-treated neutral detergent fiber in feeds with refluxing in beakers or crucibles: Collaborative study. J. AOAC Int. $85: 1217-1240$

Moore, J. A., K. R. Pond, M. H. Poore, and T. G. Goodwin. 1992. Influence of model and marker on digesta kinetic estimates for sheep. J. Anim. Sci. 70:3528-3540.

NRC. 2001. Nutrient Requirements of Dairy Cattle. 7th rev. ed. Natl. Acad. Press, Washington, DC.

Pond, K. R., W. C. Ellis, J. H. Matis, H. M. Ferreiro, and J. D. Sutton. 1988. Compartment models for estimating attributes of digesta flow in cattle. Br. J. Nutr. 60:571-595.

Poore, M. H., J. A. Moore, and R. S. Swingle. 1990. Differential passage rates and digestion of neutral detergent fiber from grain and forages in $30 \%, 60 \%$, and $90 \%$ concentrate diets fed to steers. J. Anim. Sci. 68:2965-2973.

Poppi, D. P., B. W. Norton, D. J. Minson, and R. W. Hendricksen. 1980. The validity of the critical size theory for particles leaving the rumen. J. Agric. Sci. 94:275-280.

Robinson, P. H., S. Tamminga, and A. M. Van Vuuren. 1987. Influence of declining level of feed-intake and varying the proportion of starch in the concentrate on rumen ingesta quantity, composition and kinetics of ingesta turnover in dairy cows. Livest. Prod. Sci. $17: 37-62$.

Siddons, R. C., J. Paradine, D. E. Beever, and P. R. Cornell. 1985. Ytterbium acetate as a particulate-phase digesta-flow marker. Br. J. Nutr. 54:509-519.

Sjaunja, L. O., L. Bævre, L. Junkkarinen, J. Pedersen, and J. Setälä. 1990. A Nordic proposal for an energy corrected milk (ECM) formula. Pages 156-157 in Proc. 27th Session of International Committee for Recording Productivity of Milk Animals (ICRPMA).
Eur. Assoc. Anim. Prod. Publ. No. 50. Eur. Assoc. Anim. Prod. Wageningen, the Netherlands.

Stensig, T., M. R. Weisbjerg, and T. Hvelplund. 1998. Evaluation of different methods for the determination of digestion and passage rates of fibre in the rumen of dairy cows. Acta Agric. Scand. Anim. Sci. 48:141-154.

Tamminga, S., P. H. Robinson, M. Vogt, and H. Boer. 1989. Rumen ingesta kinetics of cell wall components in dairy cows. Anim. Feed Sci. Technol. 25:89-98.

Thielemans, M. F., E. Francois, C. Bodart, and A. Thewis. 1978. Mésure du transit gastrointestinal chez le porc à l'aide des radiolanthanides: Comparison avec le mouton. Ann. Biol. Anim. Biochim. Biophys. 18:237-247.

Tilley, J. M. A., and R. A. Terry. 1963. A two-stage technique for the in vitro digestion of forage crops. Grass Forage Sci. 18:104-111.

Tothi, R., P. Lund, M. R. Weisbjerg, and T. Hvelplund. 2003. Effect of expander processing on fractional rate of maize and barley starch degradation in the rumen of dairy cows estimated using rumen evacuation and in situ techniques. Anim. Feed Sci. Technol 104:71-94.

Udén, P., P. E. Colucci, and P. J. Van Soest. 1980. Investigation of chromium, cerium and cobalt as markers in digesta. Rate of passage studies. J. Sci. Food Agric. 31:625-632.

Van Soest, P. J. 1994. Nutritional Ecology of the Ruminant. 2nd ed. Cornell Univ. Press, Ithaca, NY.

Vega, A., and D. P. Poppi. 1997. Extent of digestion and rumen condition as factors affecting passage of liquid and digesta particles in sheep. J. Agric. Sci. 128:207-215.

Volden, H. 2011. NorFor-The Nordic Feed Evaluation System. EAAP Publication. Wageningen Academic Publishers, Wageningen, the Netherlands.

Williams, C. H., O. Iismaa, and D. J. David. 1962. The determination of chromic oxide in faeces samples by atomic absorption spectrophotometry. J. Agric. Sci. 59:381-385.

Wilson, J. R., and P. M. Kennedy. 1996. Plant and animal constraints to voluntary feed intake associated with fibre characteristics and particle breakdown and passage in ruminants. Aust. J. Agric. Res. 47:199-225.

Wylie, M. J., W. C. Ellis, J. H. Matis, E. M. Bailey, W. D. James, and D. E. Beever. 2000. The flow of forage particles and solutes through segments of the digestive tracts of cattle. Br. J. Nutr. $83: 295-306$. 